\title{
Triiodothyronine levels for risk stratification of patients with chronic heart failure
}

\author{
Alessandro Pingitore, MD, PhD, ${ }^{a}$ Patrizia Landi, ${ }^{a}$ Maria Chiara Taddei, ${ }^{a}$ \\ Andrea Ripoli, PhD, ${ }^{a}$ Antonio L'Abbate, MD, ${ }^{b}$ Giorgio Iervasi, MD ${ }^{a}$
}

\author{
${ }^{a}$ From the Institute of Clinical Physiology, C.N.R., Pisa, Italy; and \\ ${ }^{b}$ Scuola Superiore S. Anna, Pisa, Italy.
}

\section{KEYWORDS:}

Chronic heart failure;

Prognosis;

Thyroid hormone
PURPOSE: We sought to explore the use of triiodothyronine $\left(\mathrm{T}_{3}\right)$ concentrations as an adjunct to clinical and functional parameters when estimating prognosis in patients with chronic heart failure.

METHODS: We enrolled 281 patients with postischemic $(n=153)$ or nonischemic $(n=128)$ dilated cardiomyopathy. Total and free $\mathrm{T}_{3}$ concentrations, and traditional clinical and functional cardiac parameters, were measured 2 to 5 days after hospital admission. A multivariate model was utilized to predict all-cause and cardiac mortality.

RESULTS: All-cause mortality was 23\% $(n=64)$ after a mean $( \pm \mathrm{SD})$ of $12 \pm 7$ months of follow-up; $47(73 \%)$ of the patients died from cardiac causes. The mean ejection fraction was lower in those patients who died than in those who survived $(26 \% \pm 8 \%$ vs. $31 \% \pm 8 \%, P<0.001)$, as were levels of total $\mathrm{T}_{3}(1.0 \pm 0.4 \mathrm{nmol} / \mathrm{L}$ vs. $1.3 \pm 0.3 \mathrm{nmol} / \mathrm{L}, P<0.001)$ and free $\mathrm{T}_{3}(3.2 \pm 1.4 \mathrm{pmol} / \mathrm{L}$ vs. $3.7 \pm 1.0 \mathrm{pmol} / \mathrm{L}, P<0.001$ ). In a multivariate model, ejection fraction (odds ratio $[\mathrm{OR}]=2.0$ per $10 \%$ decrease; $95 \%$ confidence interval $[\mathrm{CI}]: 1.4$ to 2.8 per $10 \%$ decrease; $P<0.001$ ) and total $\mathrm{T}_{3}$ level $(\mathrm{OR}=0.3$ per $1-\mathrm{nmol} / \mathrm{L}$ increase; $95 \% \mathrm{CI}: 0.1$ to 0.5 per $1-\mathrm{nmol} / \mathrm{L}$ increase; $P<0.001)$ were the only independent predictors of all-cause mortality. In an alternative model using free $\mathrm{T}_{3}$ levels, ejection fraction $(\mathrm{OR}=1.9 ; 95 \% \mathrm{CI}: 1.4$ to $2.7 ; P<0.001)$ and free $\mathrm{T}_{3}$ level $(\mathrm{OR}=0.6$ per $1 \mathrm{pmol} / \mathrm{L} ; 95 \%$ CI: 0.5 to 0.8 per $1 \mathrm{pmol} / \mathrm{L} ; P<0.02)$ were associated with all-cause mortality. When we considered cardiac mortality alone, male sex $(\mathrm{OR}=3.5 ; 95 \% \mathrm{CI}: 1.7$ to $13 ; P<0.04)$, ejection fraction $(\mathrm{OR}=$ 1.7; $95 \%$ CI: 1.2 to $2.5 ; P<0.006)$, and total $\mathrm{T}_{3}$ level (OR $=0.3 ; 95 \% \mathrm{CI}: 0.2$ to $0.7 ; P<0.002$ ) were independent predictors with the multivariate model.

CONCLUSION: Low $\mathrm{T}_{3}$ levels are an independent predictor of mortality in patients with chronic heart failure, adding prognostic information to conventional clinical and functional cardiac parameters.

(C) 2005 Elsevier Inc. All rights reserved.
Many models developed to predict prognosis in patients with heart failure incorporate neuroendocrine measurements with standard measures such as ejection fraction and severity of symptoms. ${ }^{1-7}$ Thyroid function may be particularly

Requests for reprints should be addressed to Alessandro Pingitore, MD, $\mathrm{PhD}$, C.N.R. Clinical Physiology Institute, S. Cataldo Research Campus, Via G. Moruzzi 1, 56124 Pisa, Italy.

E-mail address: pingi@ifc.cnr.it. helpful for assessing the evolution and prognosis of heart failure. ${ }^{8}$ Thyroid hormones have cardiac and vascular effects, ${ }^{9}$ and they also regulate biochemical reactions in most tissues. Altered thyroid hormone metabolism, characterized by low circulating levels of biologically active triiodothyronine $\left(\mathrm{T}_{3}\right)$, has been reported in patients following acute myocardial infarction, ${ }^{10}$ with congestive heart failure, ${ }^{11}$ and after cardiac surgery, ${ }^{12,13}$ as well as in patients with other severe systemic diseases. ${ }^{14}$ 
In an unselected sample of patients with cardiac diseases, we recently confirmed the negative prognostic value of a low $\mathrm{T}_{3}$ concentration. ${ }^{15}$ The primary goal of this study was to test whether measurement of $\mathrm{T}_{3}$ concentration could be used as an additional prognostic tool, together with classic clinical and functional parameters, for risk stratification in a selected highrisk sample of patients with chronic dilated cardiomyopathy.

\section{Methods}

\section{Sample}

Between January 1998 and July 2001, we enrolled a total of 327 consecutive hospitalized patients with postischemic or nonischemic dilated cardiomyopathy. All patients had been treated medically for heart failure for at least 1 month. The study was approved by our institutional ethics review committee, and the investigation conformed to the principles outlined in the Declaration of Helsinki. Left ventricular ejection fraction was less than $45 \%$ and left ventricular end-diastolic diameter was greater than $56 \mathrm{~mm}$ in all patients. The reason for hospital treatment was either progressive deterioration of symptoms or evidence of worse cardiac function. Postischemic dilated cardiomyopathy was diagnosed by coronary artery disease found on angiography or by documented myocardial infarction; nonischemic dilated cardiomyopathy was diagnosed based on the absence of coronary artery disease on angiography. From our initial sample, we excluded 33 patients with clinical evidence of sepsis, cachexia, or other severe systemic disease. Six patients were excluded for overt hypothyroidism (thyroidstimulating hormone [TSH] level $>10 \mathrm{mIU} / \mathrm{L}$ and free thyroxine $\left[\mathrm{T}_{4}\right]$ level $\left.<7.7 \mathrm{pmol} / \mathrm{L}[6 \mathrm{pg} / \mathrm{mL}]\right)$, and 7 were excluded for hyperthyroidism (undetectable TSH level, and free $\mathrm{T}_{3}$ level $>7 \mathrm{pmol} / \mathrm{L}[4.5 \mathrm{pg} / \mathrm{mL}]$, or free $\mathrm{T}_{4}$ level $>30$ $\mathrm{pmol} / \mathrm{L}[23 \mathrm{pg} / \mathrm{mL}])$. Thus, the final sample consisted of 281 patients; 118 (42\%) were included in our previous study. ${ }^{15}$ Left ventricular end-diastolic diameter was assessed by echocardiography and left ventricular ejection fraction by echocardiography or radionuclide ventriculography during the hospitalization. Obesity was defined as a body mass index $>30 \mathrm{~kg} / \mathrm{m}^{2}$. All data used in this study were collected between 2 and 5 days after hospital admission.

\section{Thyroid hormone measurements}

The reference intervals for our laboratory were as follows: total $\mathrm{T}_{3}, 1.2$ to $2.6 \mathrm{nmol} / \mathrm{L}$ ( 80 to $170 \mathrm{ng} / \mathrm{dL}$ ); total $\mathrm{T}_{4}$, 58 to $156 \mathrm{nmol} / \mathrm{L}$ ( 4.5 to $12 \mu \mathrm{g} / \mathrm{dL}$ ); free $\mathrm{T}_{3}, 3.2$ to 6.5 $\mathrm{pmol} / \mathrm{L}$ ( 2 to $4.2 \mathrm{pg} / \mathrm{mL}$ ); free $\mathrm{T}_{4}, 9.2$ to $24 \mathrm{pmol} / \mathrm{L}$ (7.1 to $18.5 \mathrm{pg} / \mathrm{mL}$ ); and TSH, 0.3 to $3.8 \mathrm{mIU} / \mathrm{L}$.

\section{Follow-up}

Follow-up began when thyroid hormone levels were measured. Follow-up data were obtained from hospital records, contacts with family physicians, telephone interviews with the patients, and scheduled patient visits. ${ }^{15} \mathrm{We}$ ascertained all-cause and cardiac mortality from medical records or death certificates. Cardiac death required documentation of arrhythmia or cardiac arrest, death due to progressive heart failure, or myocardial infarction in the absence of a precipitating factor. Sudden unexpected death was classified as a cardiac death when it occurred outside the hospital and was not followed by an autopsy.

\section{Statistical analysis}

Statistical evaluation was preceded by a one-sample Kolmogorov-Smirnov test to ascertain the distribution of the continuous variables. Confidence intervals for categorical data were computed by the quadratic approximation to binomial distribution with continuity correction. Association between continuous variables was evaluated by the Pearson product-moment (Pearson $r$ ) or by the Spearman rank correlation coefficient (Spearman $r$ ), as appropriate. Groups were compared for categorical data or frequency of events using the chi-squared test, and for continuous variables using the Student $t$ test or the Mann-Whitney $U$ test, as appropriate. All tests were two-sided and $P<0.05$ was considered statistically significant. Analysis of variance and Bonferroni post hoc tests were used to assess the relation between total $\mathrm{T}_{3}$ levels and New York Heart Association (NYHA) class. Continuous variables (age, ejection fraction, free $\mathrm{T}_{3}$, free $\mathrm{T}_{4}$, total $\mathrm{T}_{3}$, total $\mathrm{T}_{4}, \mathrm{TSH}$, body mass index, left ventricular end-diastolic diameter, NYHA class) and dichotomized variables (sex, hypertension, obesity, diabetes, dyslipidemia, smoking, previous myocardial infarction, diagnosis of nonischemic or postischemic dilated cardiomyopathy, documented myocardial ischemia, medical treatment) were entered in the logistic regression model to identify univariate predictors of mortality or cardiac mortality. All variables with significant univariate associations $(P$ $<0.05)$ were included in multivariate models. Cumulative survival rates at 18 months were estimated, along with $95 \%$ confidence intervals; differences in survival curves were tested with the log-rank test. All analyses were performed using SPSS for Windows (version 10.05; SPSS Inc., Chicago, Illinois).

\section{Result}

Of the 281 patients, 128 (46\%) had nonischemic dilated cardiomyopathy and 153 (54\%) had postischemic dilated cardiomyopathy. During a mean $( \pm \mathrm{SD})$ of $12 \pm 7$ months of follow-up, 64 patients (23\%) died, including 47 (73\%) of cardiac causes. Those who died were older and had worse cardiac function and lower $T_{3}$ levels, than those who survived during follow-up; they were also less likely to be dyslipidemic or obese (Table 1). 
Table 1 Characteristics of the sample

\begin{tabular}{|c|c|c|c|}
\hline Characteristic & $\begin{array}{l}\text { Died } \\
\text { during } \\
\text { follow-up } \\
(n=64)\end{array}$ & $\begin{array}{l}\text { Survived } \\
\text { throughout } \\
\text { follow-up } \\
(n=217)\end{array}$ & $P$ value \\
\hline & \multicolumn{2}{|c|}{ Number $(\%)$ or mean \pm SD } & \\
\hline Male sex & $53(83)$ & $154(71)$ & 0.08 \\
\hline Diabetes & $15(23)$ & $45(21)$ & 0.87 \\
\hline Arterial hypertension & $24(38)$ & $106(49)$ & 0.15 \\
\hline Dyslipidemia & $21(33)$ & $111(51)$ & 0.01 \\
\hline Body mass index $\left(\mathrm{kg} / \mathrm{m}^{2}\right)$ & $26 \pm 4$ & $27 \pm 5$ & 0.14 \\
\hline Obesity $\left(>30 \mathrm{~kg} / \mathrm{m}^{2}\right)$ & $10(16)$ & $22(34)$ & 0.009 \\
\hline Ischemic dilated cardiomyopathy & $32(50)$ & $98(45)$ & 0.58 \\
\hline Left ventricular end-diastolic diameter ( $\mathrm{mm})$ & $64 \pm 10$ & $61 \pm 9$ & 0.02 \\
\hline TSH (mIU/L) & $2.3 \pm 2.6$ & $1.9 \pm 2.2$ & 0.28 \\
\hline Total $\mathrm{T}_{3}(\mathrm{nmol} / \mathrm{L}) *$ & $1.0 \pm 0.4$ & $1.3 \pm 0.3$ & $<0.001$ \\
\hline Total $\mathrm{T}_{4}(\mathrm{nmol} / \mathrm{L})^{*}$ & $104 \pm 35$ & $127 \pm 67$ & 0.10 \\
\hline Free $\mathrm{T}_{3}(\mathrm{pmol} / \mathrm{L})^{*}$ & $3.2 \pm 1.4$ & $3.7 \pm 1.0$ & 0.01 \\
\hline Free $\mathrm{T}_{4}(\mathrm{pmol} / \mathrm{L}) *$ & $18.2 \pm 5.3$ & $18.1 \pm 5.0$ & 0.83 \\
\hline NYHA class (I-IV) & $2.9 \pm 1.4$ & $2.2 \pm 1.7$ & 0.003 \\
\hline Follow-up (months) & $8.4 \pm 7.3$ & $13.6 \pm 6.2$ & $<0.001$ \\
\hline
\end{tabular}

In the total sample, there was a significant correlation between levels of total $\mathrm{T}_{3}$ and free $\mathrm{T}_{3}(r=0.79, P<0.001)$, but there was no correlation between total $\mathrm{T}_{3}$ level and ejection fraction $(r=0.009, P=0.86)$. There were weak correlations between body mass index and total $\mathrm{T}_{3}$ level $(r$ $=0.13, P=0.04)$, and between NYHA class and total $\mathrm{T}_{3}$ level $(r=0.35, P=0.03)$.

\section{Stratifying risk variables and mortality}

In univariate models, age, NYHA class, ejection fraction, end-diastolic left ventricular diameter, and levels of free $\mathrm{T}_{3}$ and total $\mathrm{T}_{3}$ were associated with all-cause mortality (Table 2). In a multivariate analysis, only ejection fraction and total $\mathrm{T}_{3}$ level were independent predictors. An alternative model showed that free $\mathrm{T}_{3}$ level was also associated with all-cause mortality after adjustment for ejection fraction (when total $\mathrm{T}_{3}$ level was not included in the model).

When we considered cardiac mortality, age, sex, ejection fraction, end-diastolic left ventricular diameter, and total $\mathrm{T}_{3}$ levels were significant univariate predictors. Sex, ejection fraction, and total $\mathrm{T}_{3}$ (or free $\mathrm{T}_{3}$ ) level were the only independent multivariate predictors (Table 2).

Using cutoff values of $20 \%$ for left ventricular ejection fraction and a total $\mathrm{T}_{3}$ level of $1.2 \mathrm{nmol} / \mathrm{L}$ (the lower limit of normal), we defined four subgroups of patients (Figure
$1)$. The estimated survival of patients with an ejection fraction $>20 \%$ and total $\mathrm{T}_{3}$ level $>1.2 \mathrm{nmol} / \mathrm{L}(90 \% ; 95 \%$ confidence interval [CI]: $85 \%$ to $96 \%$ ) was significantly greater than that in patients with an ejection fraction $>20 \%$ and total $\mathrm{T}_{3}$ level $\leq 1.2 \mathrm{pmol} / \mathrm{L}$ (73\%; $95 \% \mathrm{CI}$ : $63 \%$ to $83 \%$; $P=0.002)$ and in patients with an ejection fraction $\leq 20 \%$ and total $\mathrm{T}_{3}$ level $\leq 1.2 \mathrm{pmol} / \mathrm{L}(61 \% ; 95 \% \mathrm{CI}: 41 \%$ to $81 \%$; $P<0.001)$. Survival of patients with an ejection fraction $\leq 20 \%$ and total $\mathrm{T}_{3}$ level $>1.2 \mathrm{pmol} / \mathrm{L}$ (83\%; 95\% CI: $69 \%$ to $98 \%$ ) was significantly greater than that in patients with an ejection fraction $\leq 20 \%$ and total $\mathrm{T}_{3}$ level $\leq 1.2 \mathrm{pmol} / \mathrm{L}$ (61\%; $95 \%$ CI: $41 \%$ to $81 \% ; P=0.02$ ).

\section{Discussion}

Our main finding is that $\mathrm{T}_{3}$ levels are independent predictors of all-cause and cardiac mortality in patients with dilated cardiomyopathy, and add prognostic information to conventional clinical and functional cardiac parameters. Low $\mathrm{T}_{3}$ levels had prognostic value even among patients with low ejection fractions. Because total and free $\mathrm{T}_{3}$ levels are highly correlated, they cannot both be included in the same regression model. Thus, we were unable to determine which measurement is more useful. 
Table 2 Factors associated with all-cause and cardiac mortality in univariate and multivariate logistic regression models

\begin{tabular}{|c|c|c|c|c|}
\hline \multirow[b]{2}{*}{ Characteristic (units) } & \multicolumn{2}{|l|}{ All-cause mortality } & \multicolumn{2}{|l|}{ Cardiac mortality } \\
\hline & $\begin{array}{l}\text { Odds ratio ( } 95 \% \\
\text { confidence interval) }\end{array}$ & $P$ value & $\begin{array}{l}\text { Odds ratio ( } 95 \% \\
\text { confidence interval) }\end{array}$ & $P$ value \\
\hline \multicolumn{5}{|l|}{ Univariate models } \\
\hline $\begin{array}{l}\text { Age (per } 10 \text { years) } \\
\text { Male sex } \\
\text { Ejection fraction (per 10\%) } \\
\text { End-diastolic diameter (per } 10 \mathrm{~mm} \text { ) } \\
\left.\text { Total } \mathrm{T}_{3} \text { (per } 1 \mathrm{nmol} / \mathrm{L}\right) \\
\left.\text { Free } \mathrm{T}_{3} \text { (per } 1.0 \mathrm{pmol} / \mathrm{L}\right) \\
\text { Obesity } \\
\text { NYHA (I-IV) }\end{array}$ & $\begin{array}{l}1.5(1.0-2.2) \\
1.9(0.9-4.0) \\
2.0(1.3-2.7) \\
2.2(1.5-3.2) \\
0.3(0.1-0.5) \\
0.6(0.5-0.9) \\
0.4(0.1-0.7) \\
1.3(1.1-1.6)\end{array}$ & $\begin{array}{l}0.02 \\
0.06 \\
0.001 \\
0.001 \\
0.001 \\
0.03 \\
0.006 \\
0.003\end{array}$ & $\begin{array}{l}1.7(1.1-2.8) \\
3.5(1.3-9.3) \\
1.7(1.2-2.4) \\
1.9(1.3-2.9) \\
0.4(0.2-0.7) \\
0.6(0.5-0.8) \\
0.5(0.2-1.1) \\
1.2(0.9-1.5)\end{array}$ & $\begin{array}{l}0.01 \\
0.01 \\
0.004 \\
0.01 \\
0.001 \\
0.005 \\
0.08 \\
0.06\end{array}$ \\
\hline \multicolumn{5}{|l|}{ Multivariate model with total $\mathrm{T}_{3}$} \\
\hline
\end{tabular}

The systemic actions of biologically active $T_{3}$, combined with evidence of its multisystem involvement in heart failure, provided the rationale for testing whether measuring $\mathrm{T}_{3}$ levels would be useful in risk stratification. The effects of $\mathrm{T}_{3}$ as a "whole body" marker, rather than a cardiac-specific marker, were reinforced by the absence

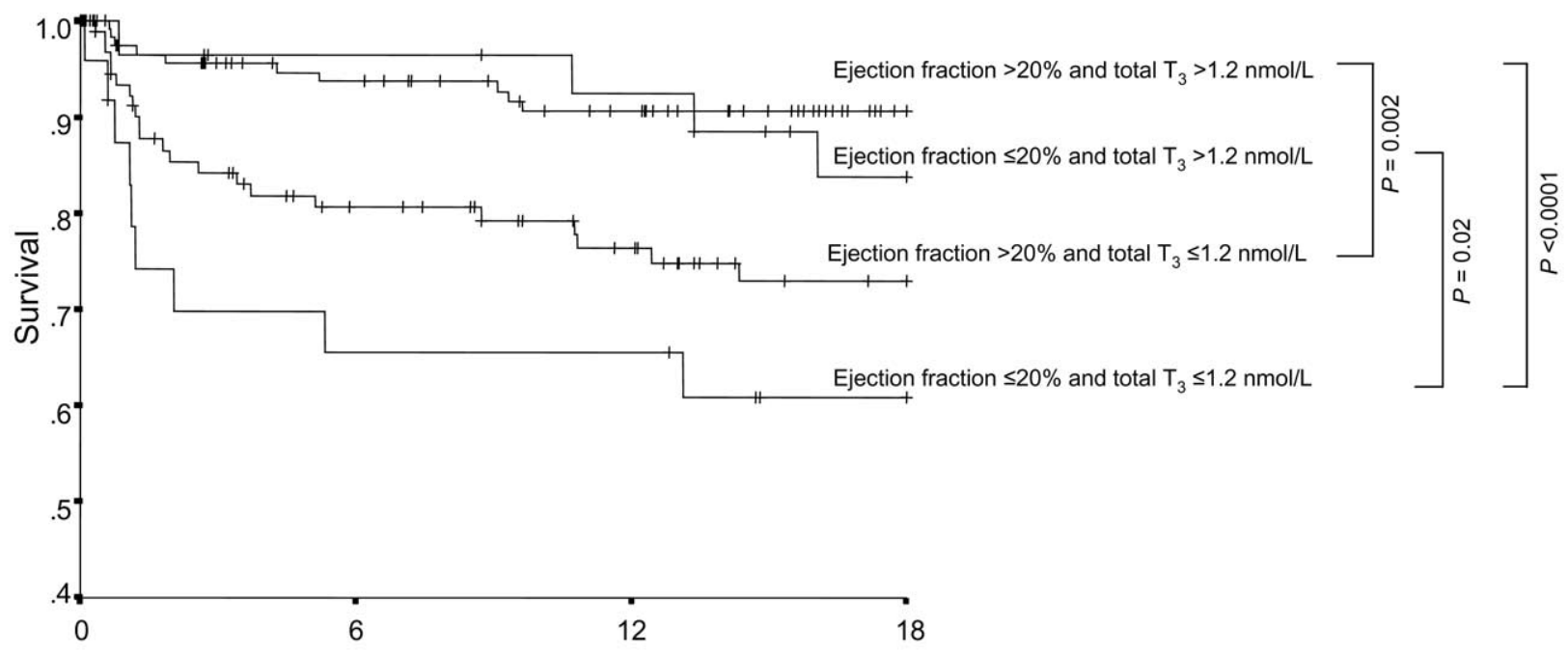

Follow-up Time (months)

No. at risk

$\begin{array}{lcccl}127 & 95 & 74 & 34 & \text { Ejection fraction }>20 \% \text { and total } \mathrm{T}_{3}>1.2 \mathrm{nmol} / \mathrm{L} \\ 32 & 27 & 12 & \text { Ejection fraction } \leq 20 \% \text { and total } \mathrm{T}_{3}>1.2 \mathrm{nmol} / \mathrm{L} \\ 97 & 24 & 23 & \text { Ejection fraction }>20 \% \text { and total } \mathrm{T}_{3} \leq 1.2 \mathrm{nmol} / \mathrm{L} \\ 25 & 60 & 47 & 9 & \text { Ejection fraction } \leq 20 \% \text { and total } \mathrm{T}_{3} \leq 1.2 \mathrm{nmol} / \mathrm{L}\end{array}$

Figure 1 Kaplan-Meier 18-month survival curves in four subgroups identified according to the cutoff values of $20 \%$ for left ventricular ejection fraction and triiodothyronine $\left(\mathrm{T}_{3}\right)$ levels of $1.2 \mathrm{nmol} / \mathrm{L}$. 
of any direct correlation between $\mathrm{T}_{3}$ level and ejection fraction.

Low $\mathrm{T}_{3}$ levels may not be an adaptation to chronic illness that minimize catabolism; ${ }^{8,10}$ accordingly, the high mortality of patients with very low $\mathrm{T}_{3}$ levels is not surprising. Our results are also consistent with the adverse prognosis associated with increased peripheral production of biologically inactive reverse $\mathrm{T}_{3}$ after acute myocardial infarction. ${ }^{10} \mathrm{In}-$ deed, altered thyroid metabolism may be implicated directly in the progression of heart failure. , 16-23 $^{-23}$

$\mathrm{T}_{3}$ measurement offers a number of advantages-it is a simple, inexpensive, and reliable blood test that can be measured at most medical laboratories, unlike several other biohumoral markers like serum norepinephrine levels. ${ }^{24,25}$

In contrast with our previous study, in which the prognostic value of $\mathrm{T}_{3}$ levels was demonstrated in moderately ill patients with various cardiac diseases ${ }^{15}$ the present results were obtained in patients who had been hospitalized for chronic heart failure. Thus, mortality was much higher than in our previous study, although similar to recent reports from similar samples. ${ }^{26}$

In conclusion, $\mathrm{T}_{3}$ measurement is useful for risk stratification of patients with heart failure. Whether it adds prognostic value to measurements of natriuretic peptide levels remains to be determined. Further studies are needed to assess whether low $\mathrm{T}_{3}$ levels are just prognostic markers or are implicated directly in the progression of heart failure.

\section{Acknowledgment}

We would like to thank Laura Mazza for her secretarial assistance, Sarah Hills for editorial assistance, and Mauro Raciti for statistical analysis.

\section{References}

1. Packer M: Neurohormonal interactions and adaptations in congestive heart failure. Circulation. 1998;77:721-730.

2. Mann DL: Mechanisms and models in heart failure. A combinatorial approach. Circulation. 1999;100:999-1008.

3. Cohn J, Levine T, Olivari M, et al. Plasma norepinephrine as a guide to prognosis in patients with chronic congestive heart failure. $N$ Engl J Med. 1984;311:819-823.

4. Benedict CR, Shelton B, Johnstone DE, et al. Prognostic significance of plasma norepinephrine in patients with asymptomatic left ventricular dysfunction. SOLVD Investigators. Circulation. 1996;94:690697.

5. Pitt B, Zannad F, Remme WJ, et al. The effect of spironolactone on morbidity and mortality in patients with severe congestive heart failure. N Engl J Med. 1999;341:709-717.
6. Koglin J, Pehlivanli S, Schwaiblmair M, et al. Role of brain natriuretic peptide in risk stratification of patients with congestive heart failure. J Am Coll Cardiol. 2001;38:1934-1941.

7. Madsen B, Keller N, Christiansen E: Prognostic value of plasma catecholamines, plasma renin activity, and plasma atrial natriuretic peptide at rest and during exercise in congestive heart failure: comparison with clinical evaluation, ejection fraction and exercise capacity. J Card Fail. 1995;1:207-216.

8. Klein I, Ojamaa K. Thyroid hormone treatment of congestive heart failure. Am J Cardiol. 1998;81:490-491.

9. Klein I, Ojamaa K. Thyroid hormone and the cardiovascular system. N Engl J Med. 2001;344:501-509.

10. Friberg L, Werner S, Eggertsen G, et al. Rapid down-regulation of thyroid hormones in acute myocardial infarction: is it cardioprotective in patients with angina? Arch Intern Med. 2002;162:1388-1394.

11. Hamilton MA, Stevenson LW, Lu M, et al. Altered thyroid hormone metabolism in advanced heart failure. $J$ Am Coll Cardiol. 1990;16: 91-95.

12. Murzi B, Iervasi G, Masini S, et al. Thyroid hormones homeostasis in pediatric patients during and after cardiopulmonary by-pass. Ann Thorac Surg. 1995;59:481-485.

13. Holland FW, Brown PS Jr, Weintraub BD, et al. Cardiopulmonary bypass and thyroid function: a "euthyroid sick syndrome". Ann Thorac Surg. 1991;52:46-50.

14. Camacho PM, Dwarkanathan AA. Sick euthyroid syndrome. What to do when thyroid function tests are abnormal in critically ill patients. Postgrad Med. 1999;105:215-219.

15. Iervasi G, Pingitore A, Landi $P$, et al. Low-T3 syndrome: a strong prognostic predictor of death in patients with heart disease. Circulation. 2003;107:708-713.

16. Forini F, Paolicchi A, Pizzorusso T, et al. 3,5,3'-triiodothyronine deprivation affects phenotype and intracellular $(\mathrm{Ca} 2+) \mathrm{I}$ of human cardiomyocytes in culture. Cardiovasc Res. 2001;51:322-330.

17. Ojamaa K, Kenessey A, Shenoy R, et al. Thyroid hormone metabolism and cardiac gene expression after acute myocardial infarction in the rat. Am J Physiol Endocrinol Metab. 2000;279:E1319-E1324.

18. Walker JD, Crawford FA, Kato S, et al. The novel effects of 3,5,3'triiodo-L-thyronine on myocyte contractile function and $\beta$-adrenergic responsiveness in dilated cardiomyopathy. J Thorac Cardiovasc Surg. 1994;108:672-679.

19. Hamilton MA, Stevenson LW, Fonarow GC. Safety and hemodynamic effects of intravenous triiodothyronine in advanced congestive heart failure. Am J Cardiol. 1998;81:443-447.

20. Malik FS, Mehra MR, Uber PA, et al. Intravenous thyroid hormone supplementation in heart failure with cardiogenic shock. J Card Fail. 1999;5:31-37.

21. Bengel FM, Nekolla SG, Ibrahim T, et al. Effect of thyroid hormones on cardiac function, geometry, and oxidative metabolism assessed noninvasively by positron emission tomography and magnetic resonance imaging. J Clin Endocrinol Metab. 2000;85:1822-1827.

22. Moruzzi P, Doria E, Agostoni PG. Medium term effectiveness of 1-thyroxine treatment in idiopathic dilated cardiomyopathy. Am J Med. 1996;101:461-467.

23. Di Pierro FV, Bavaria JE, Lankford EB, et al. Improved cardiac output and enhanced cardiac mechanical efficiency with acute administration of T3. Ann Thorac Surg. 1996;62:662-669.

24. Ghione S, Del Chicca MG, Gazzetti P, Zucchelli GC. Circulating cathecolamines: a reapproisal. Intern Med. 1997;5:93-100.

25. Bozkurt B, Mann DL. Use of biomarkers in the management of heart failure. Are we there yet? Circulation. 2003;107:1231-1233.

26. Guyatt GH, Devereaux PJ. A review of heart failure treatment. $M t$ Sinai J Med. 2004;71:47-54. 